\title{
Cell Lysis Method Affects Assessment of Microbial Diversity Based on Ribotyping Analysis
}

\author{
HENI YOHANDINI ${ }^{1}$, FIDA MADAYANTI ${ }^{1}$, PINGKAN ADITIAWATI $^{2}$, AND AKHMALOKA ${ }^{1 *}$ \\ Biochemistry Research Division, Faculty of Mathematics and Natural Sciences ${ }^{1}$, \\ School of Life Sciences and Technology ${ }^{2}$, Institut Teknologi Bandung, \\ Jalan Ganesha 10, Bandung 40132, Indonesia
}

\begin{abstract}
The microbial community in Kawah Hujan, Kamojang, West Java, Indonesia, was analyzed using 16S-rRNA-gene-sequencing combining with denaturing-gradient-gel electrophoresis (DGGE) technique. Two different cell lysis methods, enzymatic-based, and physical treatment-based DNA extraction, were used to isolate chromosomal DNA for 16S rDNA gene-fragment amplification. The DGGE profiles showed some differences in banding pattern that were obtained from both cell lysis methods. The DNA sequence analysis of the individual DGGE bands revealed that most of the band sequences obtained by physical treatment were close to 16S rRNA gene fragments from the bacterial domain, while most of band sequences performed by enzymatic method had high homology with 16S rRNA gene fragments from archaeal domain. Further analysis of the sequences from both methods performed by comparisons with the Ribosomal Database Project showed that some of DGGE sequences from Kawah Hujan consisted unique 16S rDNA sequences.
\end{abstract}

Keywords: Kamojang, microbial diversity, 16S rRNA, denaturing-gradient-gel electrophoresis

An accurate measurement of microbial diversity in the environmental samples has long challenged the microbiologist and the microbial ecologist. Few microbes have sufficiently distinct cellular morphologies to be identified by microscopic techniques. However, conventional cultivations of microorganisms are laborious, time consuming and most importantly, selective and biased for the growth of specific microorganisms. Some microbes could only be cultivated if their metabolic and physiological requirements were reproduced in vitro (Nadkarni et al. 2002; Zengler et al. 2002).

Methods used to characterize microbial diversity in the environment that is independent of cultivation have been developed in recent times (Marsh et al. 2000; Sekiguchi et al. 2002; Nakagawa and Fukui 2003; Ashby et al. 2007). One such method is the molecular phylogenetic analysis of the small subunit ribosomal RNA (SSU rRNA) by sequencing, DGGE, or restriction fragment length polymorphism analyses. This approach was used for the study of marine, soils, thermal, acidic, alkaline, and hyper-saline habitats and has resulted in the discovery of new phylogenetic groups of both bacteria and archaea (Bintrim et al. 1997; Nakagawa and Fukui 2003; Sait et al. 2006; Spear et al. 2007). These studies showed that the diversity of microbial ecosystems is typically 100 to 1000 times greater than that found in cultivation alone (Skirnisdottir et al. 2001; Spear et al. 2007).

DGGE is one technique that is frequently used to measure complexity of microbial communities and to study their dynamics and to infer the phylogenetic relationship of the community members (Muyzer et al. 1993; Heuer et al. 1999; Lohr et al. 2006). DGGE analysis involves the separation of PCR-amplified 16S rRNA-gene-segments in an acrylamide gel denaturing gradient. The separation is based on differences in melting characteristics of the double-stranded DNA segments, which are in turn

\footnotetext{
*Corresponding author, Phone: +62-22-2515032 Fax: +62- 22-2502360, E-mail: loka@chem.itb.ac.id
}

dependent upon sequence differences. The result is the simultaneous detection of many individual $16 \mathrm{~S}$ rRNA molecules as a profile made up of bands, each of which can be re-amplified and then sequenced (Ward et al. 1998; Aminin et al. 2007).

Extraction of pool of DNA from the community in reasonable quantity is an important step in molecular analysis of microbial communities. No universal method for extraction of community DNA from samples of varied origin is available. Comparative studies have been performed to analyze the efficiency of methods for extraction and purification DNA from soil and sediment (Zhou et al. 1996; Chauduri et al. 2006). The differences in DGGE/TGGE profile caused by different lysis methods have been reported previously (Muyzer and Smalla 1998). DGGE/ TGGE patterns of PCR products from bacterial genomic DNA extracted from soil samples using a harsh lysis method (i.e. lysozyme plus SDS and bead-beating) gave more bands and more intense bands than profiles of PCR products obtained from the same sample by using a soft lysis method (i.e. lysozyme and alkaline SDS). Differences in DGGE patterns were also found by comparing two different lysis methods, i.e., beadmill homogenization alone versus a combination of freeze-thawing, lysozyme and SDS treatment, and beadmill homogenization (Liesack et al. 1997; Muyzer and Smalla 1998). However, the impact of the extraction method on the outcome of indigenous microbial community analysis has not yet been clearly established (Kresk et al. 1999).

In this report we describe the genomic DNA differences in microbial community using samples from the Kawah Hujan crater, West Java, extracted by using two differences cell lysis, enzymatic, and physical treatment-based methods.

\section{MATERIALS AND METHODS}

Sampling. Water samples were collected from one of Kawah Hujan craters (E 10748'14.38", N -78'21.7" and the altitude 1690 m), Kamojang, West Java. The crater has 
a temperature at $90^{\circ} \mathrm{C}$ and $\mathrm{pH} 1.9$. Microorganisms in 11 of water sample were collected on a $0.22-\mu \mathrm{m}$-pore-size Millipore membrane filter by filtration within $4 \mathrm{~h}$ after sampling. The cells on the membrane were re-suspended in $25 \mathrm{ml}$ of STE buffer [10 mM Tris-HCl ( $\mathrm{pH} 8.0), 0.1 \mathrm{M} \mathrm{NaCl}, 1 \mathrm{mM}$ EDTA] and pelleted by centrifugation. The pellets containing microbial communities were stored at $-20^{\circ} \mathrm{C}$ until DNA extraction.

Bead Beating/SDS-Based DNA Extraction. The pellets containing microbial cells were mixed with $350 \mu \mathrm{l}$ of DNA extraction buffer [100 mM Tris- $\mathrm{HCl}(\mathrm{pH} 8.0), 100$ mM sodium EDTA ( $\mathrm{pH} 8.0), 100 \mathrm{mM}$ sodium phosphate (pH 8.0), and $1.5 \mathrm{M} \mathrm{NaCl}$ ], $0.2 \mathrm{~g}$ glass beads and $20 \mu \mathrm{l}$ of proteinase-K (10 $\left.\mathrm{mg} \mathrm{ml}^{-1}\right)$ in microcentrifuge tubes by vortexing at medium speed for $15 \mathrm{~min}$ at room temperature. After the mixing treatment, $30 \mu 1$ of $20 \%$ SDS was added, and the samples were incubated at $65^{\circ} \mathrm{C}$ for $2 \mathrm{~h}$ with gentle end-over-end inversions every 15 to $20 \mathrm{~min}$. Supernatants were mixed with an equal volume of chloroform isoamylalcohol $(24: 1 \mathrm{v} / \mathrm{v})$. The aqueous phase was recovered by centrifugation and precipitated with 0.6 volume of isopropanol at room temperature for $1 \mathrm{~h}$. The pellet of crude nucleic acids were obtained by centrifugation at $16000 \mathrm{~g}$ for $20 \mathrm{~min}$ at room temperature, washed with cold $70 \%$ ethanol, and re-suspended in sterile deionized water, to give a final volume of $50 \mu \mathrm{l}$.

Lysozyme/SDS-Based DNA Extraction. The pellet cells were suspended in $200 \mathrm{il} \mathrm{of} 10 \mathrm{mM}$ Tris $\mathrm{HCl}$ buffer $(\mathrm{pH} 8.0)$ containing $8 \mathrm{mg} \mathrm{ml}^{-1}$ of lysozyme and incubated at $37^{\circ} \mathrm{C}$ for $1 \mathrm{~h}$, the cells were lysed by adding 200 il lysis buffer containing $2 \% \mathrm{SDS}, 0.8 \mathrm{mg} \mathrm{ml}^{-1}$ proteinase $\mathrm{K}$ and 200 $\mathrm{mM}$ EDTA $\mathrm{pH}$ 8.0. The lysis process was carried out by incubation at $50^{\circ} \mathrm{C}$ for $30 \mathrm{~min}$. 150 il ice cold potassium acetate and acetic acid glacial mixed solution were added and the denatured proteins were precipitated by centrifugation. Crude DNA's were processed as for the bead-beating method above.

Amplification of 16S rRNA Gene-Fragments. The amplification of fragments of DNA coding for $16 \mathrm{~S}$ rRNA was performed by touch-down PCR using primer as stated in Table 1. One primer complements a region conserved among Bacteria (corresponding to positions at 1055 to 1070 in the E. coli DNA sequence of the $16 \mathrm{~S}$ rRNA gene). The other primer was based on a universally conserved region (corresponding to positions at 1392 to 1406 in the E. coli sequence, with additional 40-base GC clamp). These primers were designed to amplify $16 \mathrm{~S}$ rRNA gene fragments in the Bacteria domain (Ferris et al. 1996). PCRs were performed by using cloned Taq DNA polymerase according to the instructions provided by the manufacturer (Promega). The temperature cycle for the PCR was $1 \mathrm{~min}$ of denaturation at $94^{\circ} \mathrm{C}, 1 \mathrm{~min}$ of annealing, and $1 \mathrm{~min}$ of primer extension at $72^{\circ} \mathrm{C}$. During an initial touchdown cycle, the annealing temperature was continually decreased from 53 to $43^{\circ} \mathrm{C}$ in intervals of $1^{\circ} \mathrm{C}$ per cycle; 20 additional annealing cycles were performed at $43^{\circ} \mathrm{C}$. The final primer extension was for $10 \mathrm{~min}$ at $72^{\circ} \mathrm{C}$.

DGGE and Re-Amplification of 16S rRNA-GeneFragments. DGGE was performed by using D-code systems (Bio-Rad Laboratories) with a 1.5-mm gel. Approximately
Table 1 The primer sequences

\begin{tabular}{ll}
\hline Primer & \multicolumn{1}{c}{ Primer sequence $\left(5^{\prime} ! 3^{\prime}\right)$} \\
\hline P1 & ATGGCTGTCGTCAGCT \\
P2 & CGCCCGCCGCGCCCCGCGCCCGGCCCGCCGCCCCCGCCC \\
& CACGGGCGGTGTGTAC \\
\hline
\end{tabular}

100- to 500-ng portions of PCR products were applied directly onto $8 \%(\mathrm{w} / \mathrm{v})$ polyacrylamide gels with denaturing gradients from 30 to $40 \%$ [100\% denaturant was $7 \mathrm{M}$ urea and $40 \%$ $(\mathrm{v} / \mathrm{v})$ deionized formamide]. Electrophoresis was performed with $0.5 X$ TAE buffer ( $20 \mathrm{mM}$ Tris, $10 \mathrm{mM}$ acetic acid, 0.5 $\mathrm{mM}$ EDTA, and $\mathrm{pH} 8.3$ ) at $200 \mathrm{~V}$ and $60^{\circ} \mathrm{C}$ for $4 \mathrm{~h}$. After electrophoresis, the gels were stained using the silver staining method (Bassam et al. 1991). Each band in the DGGE gel was excised with a razor blade and then placed in $50 \mu 1$ of Tris-EDTA buffer and incubated overnight at $37^{\circ} \mathrm{C}$. The eluted DNA was re-amplified using the same primers as previous but without GC clamps. PCRs were performed at the following conditions: an initial denaturation step at $94^{\circ} \mathrm{C}$ for $5 \mathrm{~min}$, followed by 30 cycles of $1 \mathrm{~min}$ at $94^{\circ} \mathrm{C}, 1 \mathrm{~min}$ at $50^{\circ} \mathrm{C}, 1 \mathrm{~min}$ at $72^{\circ} \mathrm{C}$, and a final extension step of $10 \mathrm{~min}$ at $72^{\circ} \mathrm{C}$. All of re-amplification results were used for DNA sequencing.

Sequence Analysis. The sequencing results were compared with DNA sequences from GenBank database at NCBI (National Centre of Biotechnological Information) through web site http://www. ncbi.nlm.nih.gov using the BLAST program (Altschul et al.1990) for screening sequence similarity. Sequence alignments were performed by the ClustelX program. Phylogenetic reconstruction was accomplished using the phylogeny inference package (PHYLIP version 3.62). Evolutionary distances were calculated by the Kimura 2-parameter method with the DNADIST program (Felsenstein 1989). Phylogenetic trees were constructed from distance matrices by the neighbor-joining method (Saitou and Nei 1987), which was implemented using the NEIGHBOR program. The node reproducibility for tree topology was estimated by bootstrap analysis, which included 1000 replicate data sets.

\section{RESULTS}

Chromosomal DNA and 16S rRNA-Gene-Fragments. Based on the examination of Et-Br stained agarose gels, chromosomal DNAs extracted by the bead beating-based DNA extraction method gave more intense bands compared to that the lysozyme method (Fig 1) when comparing equal amount of the samples. However, the DNA supernatant from the first method was darker in color, being a yellowish-brown (data not shown). Chromosomal DNA extracted by the lysozyme-based method requires additional purification step besides the chloroform-isoamylalcohol extraction to remove protein from the supernatant. This protein contamination often inhibited DNA amplification. Total chromosomal DNAs from both methods were used as a DNA template for the amplification of partial 16S-rRNA-genes without further purification. The amplification of 16S-rRNA-gene fragments had been successfully carried out, resulting in single bands of sizes expected (Fig 2).

DGGE Profiles of 16S-rRNA-Gene-Fragments. $16 \mathrm{~S}$ rRNA genes fragments were separated by DGGE. The 


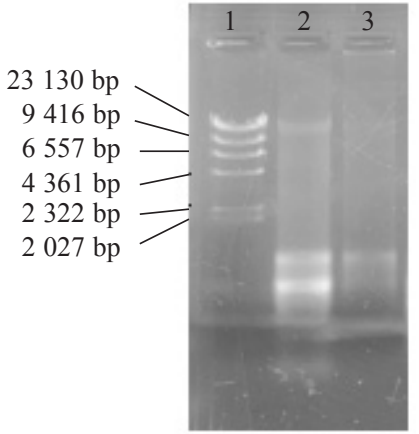

Fig 1 Electrophoregram of the chromosomal DNA. 1, $\lambda /$ HindIII markers; 2 , Chromosomal DNA extracted by bead beating-based method; 3, Chromosomal DNA extracted by lysozyme-based method.

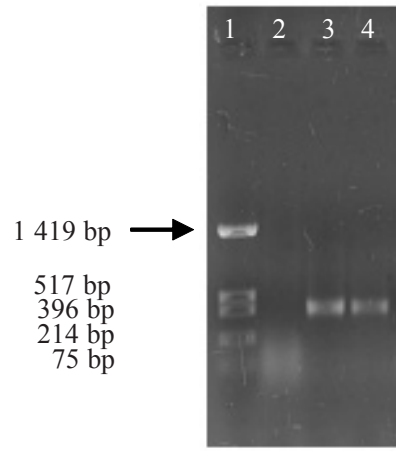

Fig 2 Amplification product of 16S rRNA gene fragments. 1, pUC19/ HinfI; 2, contamination control of the PCR process; 3 , PCR products from chromosomal DNA extracted by bead beating-based method; 4, PCR product from chromosomal DNA extracted by lysozyme-based method.

profiles of bands representing the microbial community of Kawah Hujan using both DNA extraction methods are shown in Fig 3. Different chromosomal DNA isolation methods gave different DGGE profiles. The bands from the physical treatment method appeared at the upper and lower areas of the gel (Fig 3, lane 1), while the bands from the lysozyme treatment method were distributed throughout the gel (Fig 3, lane 2). Variations in denaturant gradient concentration gave a different pattern of band separation (data not shown). However, the best separation of the bands was obtained at a concentration of $30-40 \%$ of denaturant.

Phylogenetic and Homological Analysis of 16S-rRNAGene-Sequences. Phylogenetic trees of 16S-rRNA-gene sequences were constructed based on the distance matrix methods as stated in the methodology. The tree showed that most of the sequences obtained by physical treatment were clustered on separated branch (Fig 4). One band (K3-Z-4) was a new branch compared to most of others and close to Xenorhabdus chiersii. Two bands (K3-Z-9 and K3-Z-8) were similar to each other and close to Enterobacter sp., while K3-Z-15 was far away from others but close to Pseudomonas (Fig 4). However, all of band sequences from the physical treatment were bacterial 16S-rRNA-gene sequences. In contrast, most of bands recovered from enzymatic treatment had no similarity to $16 \mathrm{~S}$ rRNA gene sequences from the bacterial domain (Fig 5b), except for K3-K-11 and K3-K-12 which were close to the glacial ice bacterium and Pseudomonas (Fig 5a).

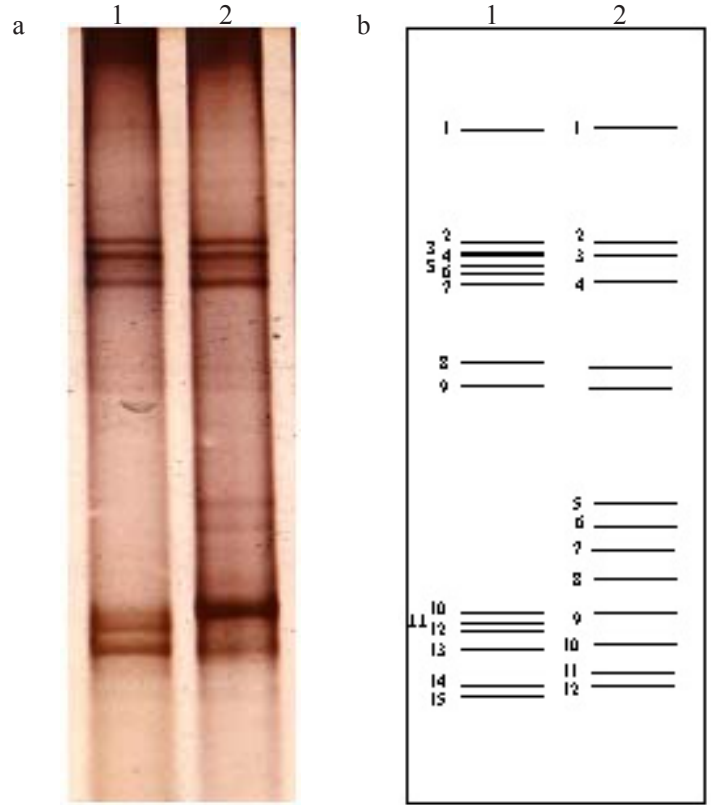

Fig 3 a, DGGE profiles of Kawah Hujan microbial community from which individual bands were excised; $b$, numbering pattern of bands which were excised and reamplified; 1, performed by using bead beating-based cell lysis method; 2, performed by using lysozyme-based cell lysis method.

The rest of the band sequences made clusters similar to each other and were similar to Sulfolobus yangmingensis (Fig 5b). One band, K3-K-13 (Fig 5b), formed a different branch far away from the others but still close to the branch of other archaeal types.

Further analysis of the homological sequences made by comparing the sequences performed by using enzymatic lysis to the closest archael 16S-rRNA-sequences from the database (Genbank) showed that many nucleotide substitutions were present in the Kamajong sequences (Fig 6). This substitution also revealed that the sequences performed by physical treatment (Fig 7) were similar, although the subsitutions were less frequent compared to that for the enzymatic lysis.

\section{DISCUSSION}

The microbial community from one of the Kawah Hujan craters was assessed by ribotyping analysis. The bands pattern from DGGE analysis showed that there were differences between the pattern obtained from enzymatic and physical extraction methods (Fig 3). This suggested that the PCR amplicons represented different communities. Further analysis by re-amplification and sequencing of each band proved that each single band represented a different strain of microorganism (Fig 4 and 5). As stated previously, most of sequences from chromosomal DNA extracted by physical treatment represented that of bacterial groups, while that extracted by enzymatic treatment more closely represented archaeal groups. This result was surprising, that the two methods gave meaningful differences at the domain level.

Chromosomal DNAs extracted by enzymatic treatment were less abundant than that the other extraction method. According to Frostegard et al. (1999), the low 


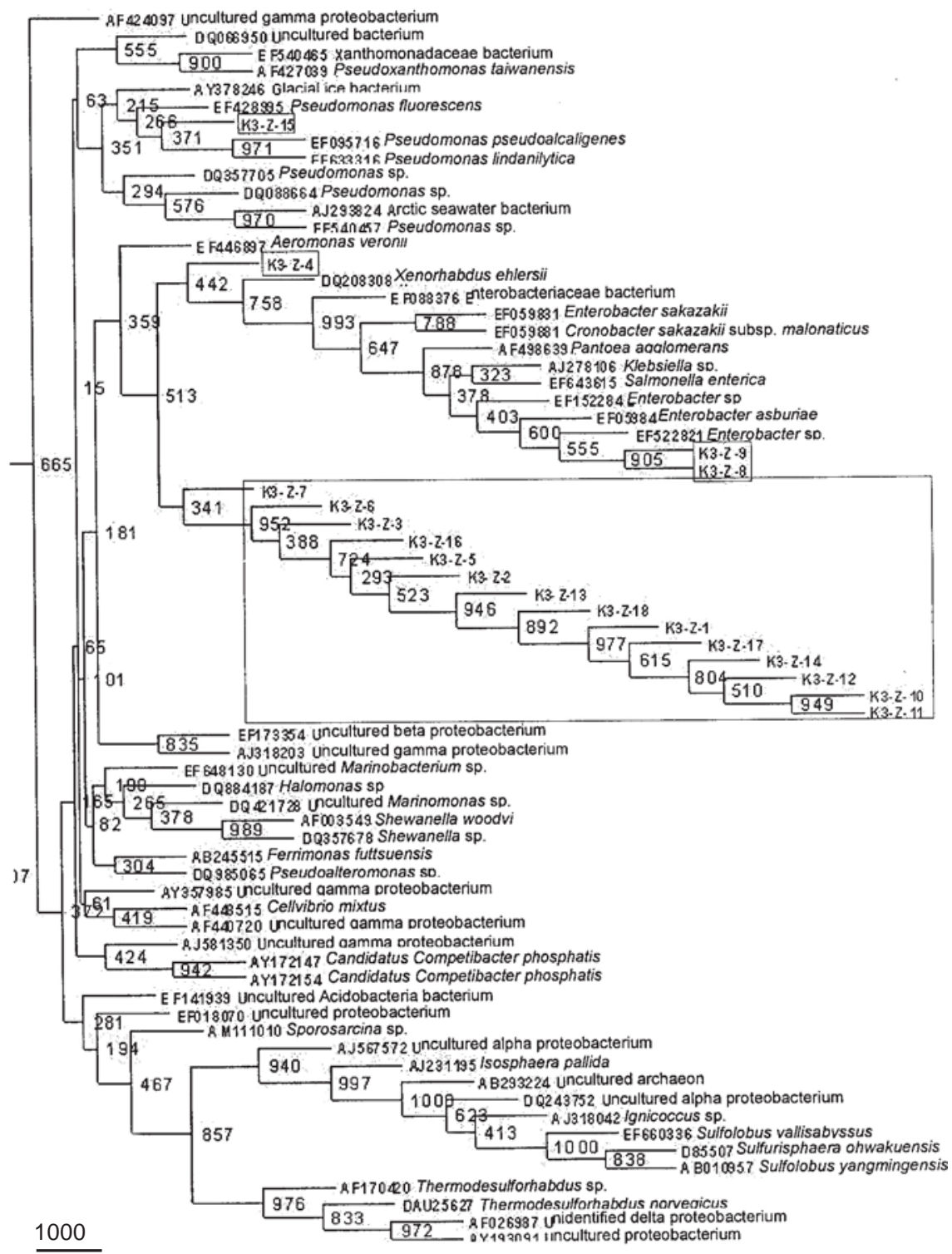

Fig 4 Phylogenetic tree of sequences performed by using bead beating-based cell lysis method. Squares $(\square)$ show position of the samples.

efficiency of DNA extraction was mainly due to incomplete cell lysis in by addition to the fact that DNA was adsorbed onto soil or mud particles during the extraction. However, physical treatment could improve the efficiency of DNA extraction compared with enzymatic treatment due to its better ability to disrupt the cells, even some of DNA was absorbed onto the particles.

We used a set of primers to amplify 16S-rRNA-genefragments that were designed to recover all of the $16 \mathrm{~S}$ rRNA gene sequences from bacterial domain. These primers have been reported to recover sequences from members of cyanobacteria, green sulfur and green non-sulfur bacteria, proteobacteria, gram-positive, and Thermus 16S rRNA genes (Ferris et al. 1996; Aminin et al. 2007). According to homological analysis of DGGE band sequences, the microbial community extracted by lysozyme-based methods mostly belonged to the archaeal domain, whereas the bead beating-based method extracted the microbial community in the bacterial domain. This result suggested that the primers also amplified 16S rRNA gene from members of archaea, besides bacteria. In our results there was no obvious difference in the intensity of bands of the PCR product, but the DGGE patterns of both amplicons were completely different. 16S-rRNA-gene fragments from the physical treatment gave more bands than did the profiles of PCR products obtained from the same sample using the enzymatic method. These results support previous reports (Muyzer and Smalla 1998; Chaudhuri et al. 2006).

In most cases, physical-based methods were able to disrupt a wide range of cell types with high DNA yields, but could shear the chromosomal DNA to smaller fragments (Liesack et al. 1997). However, enzymatic-based methods were usually more selective and resulted in higher molecular weight of the chromosomal DNA (Muyzer and Smalla 1998). We expected that physical treatment could recover DNA from a more wide-ranging diversity of microbes compared to the enzymatic treatment. In spite of this, the results did not provide evidence for this assumption. We suggest that differences in the lysis method select different members of the microbial community. The enzymatic-based 

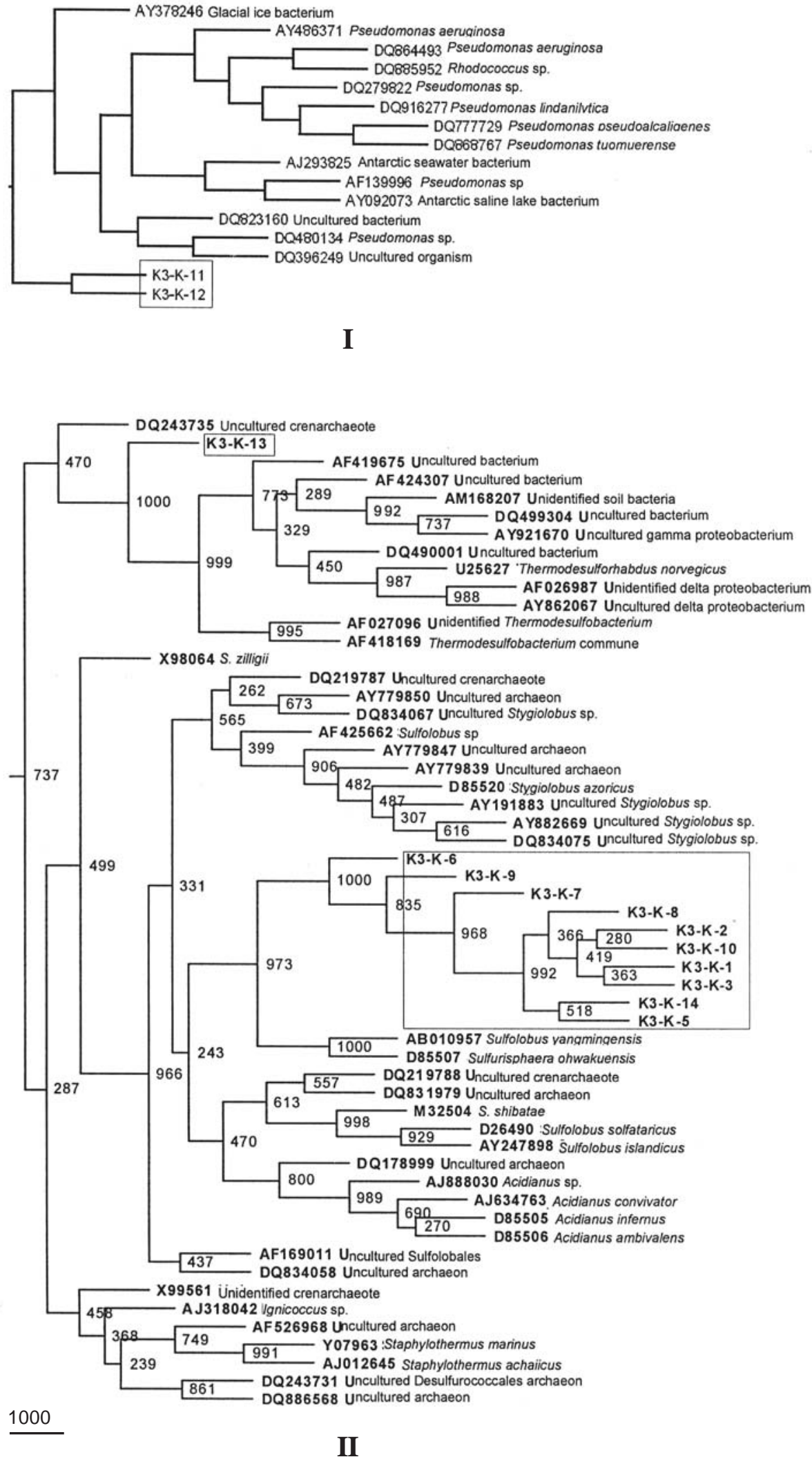

Fig 5 Phylogenetic tree of sequences performed by using lysozyme-based cell lysis method. The trees were separated into I and II due to the long distance between the archaeal and bacterial domains. Squares $(\square)$ show position of the samples.

method had limited ability to isolate chromosomal DNA of unexposed microbes in the spring water, for example by entrapping microbes in sludge. In this study most of microbes identified by enzymatic-based method were close to the archaeal domain. This was suggested by the fact that these organisms grew exposed in the spring water. Meanwhile the physical treatment methods had possibility to release unexposed microbes so that the chromosomal DNA could be isolated. In our results, the physical treatment method recovered most of bacterial domain (Fig 4). 


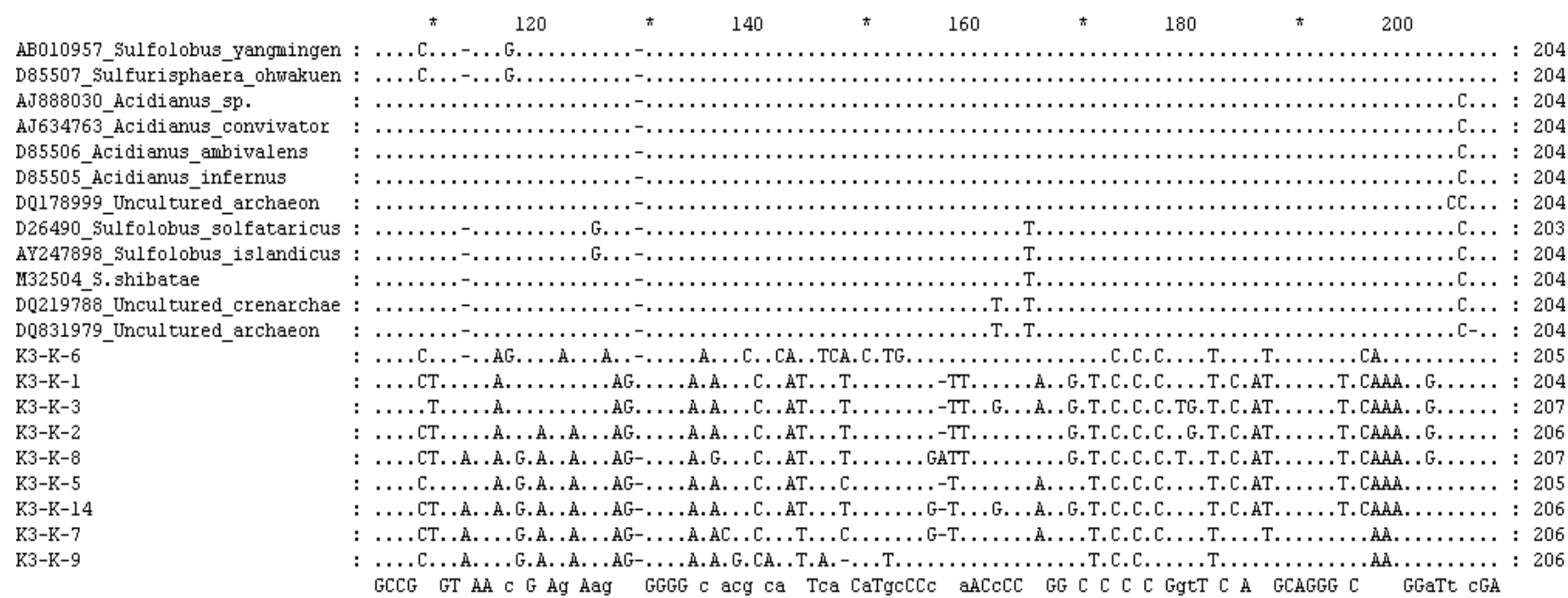

Fig 6 Alignment analysis of the sequences performed by using enzymatic-lysis with some archaea sequences from Genbank The bottom sequences was the consensus, $\left({ }^{*}\right)$ no substitution.

AF498639_Pantoea_agglomerans
BF643615_Salmone1la_enterica
AJ278106_Klebsiella_sp.
BF152284_Enterobacter_sp.
K3-2-8
K3-2-9
BF522821_Enterobacter_sp.
BF059842_Enterobacter_asburiae
BF059831_Enterobacter_sakazaki
BF05988__Cronobacter_sakazakii
BF088376_Enterobacteriaceae
DQ208308_Xenorhabdus_ehlersii
K3-2-4
BF446897_Aeromonas_veronii
K3-2-7
K3-2-3
K3-2-6
K3-2-5
K3-2-2
K3-2-14
K3-2-11
K3-2-12
K3-2-10
K3-2-1
K3-2-13

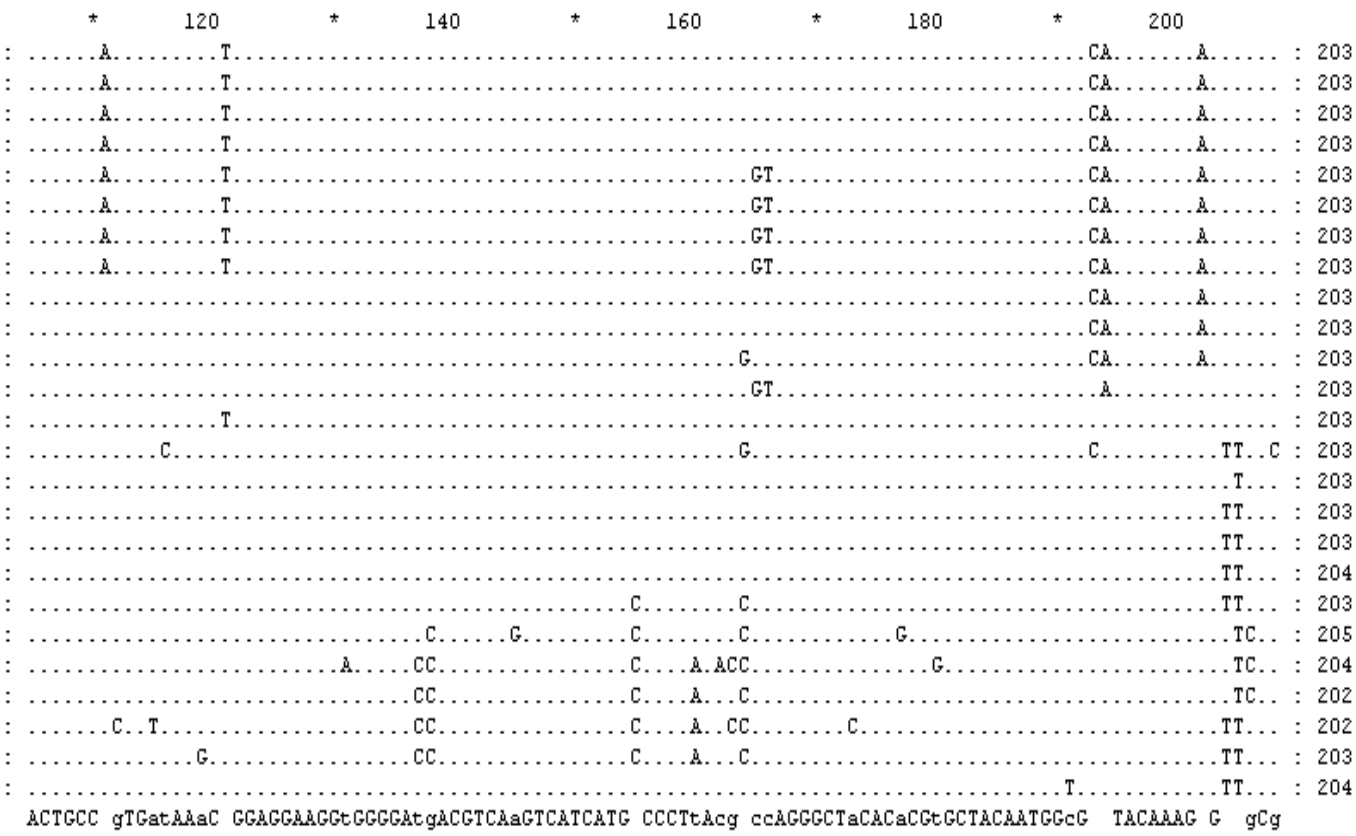

Fig 7 Alignment analysis of the sequences performed by using physical-lysis with some Proteobacter sequences from Genbank. The bottom sequences was the consensus, ( ${ }^{*}$ ) no substitution.

This was suggested by the fact that the bacteria grow in association to sludge in the springs. This is probably due to the fact that the spring was not an ideal habitat for these organisms. Meanwhile, for most of the archaea such as Sulfolobus, the spring water provided suitable conditions for growth (Lohr et al. 2006).

Most of the 16S-rDNA sequences from both the enzymatic and physical extraction methods were unique. Many substitutions occurred in the sequences from enzymatic extraction (10-15\%) compared to that the closest archael sequences from the GenBank. On the other hand, using physical extraction these substitutions were less frequent. It is a well known that the differences above $5 \%$ on the $16 \mathrm{~S}$ rRNA gene sequences are believed to be due to different strains (Ashby et al. 2007). This is suggested by the fact that most of the sequences from enzymatic treatment belong to novel archaea strains, probably unique to Kawah Hujan, Kamojang.
From all of data obtained in this study, we proposed that the Kawah Hujan, Kamojang habitat contains a lot of novel thermophilic microorganisms. We also recommend using more than one lysis method for assessing microbial communities in nature.

\section{ACKNOWLEDGEMENT}

This research was funded by grant from Program Riset KK, Fakultas Matematika dan Ilmu Pengetahuan Alam, Institut Teknologi Bandung to Akhmaloka and Insentif Riset Dasar, KMRT, to Fida Madayanti.

\section{REFERENCES}

Altschul SF, Gish W, Miller W, Myers EW, Lipman DJ. 1990. Basic local alignment search tool. $J$ Mol Biol 215:403-410. 
Aminin ALN, Madayanti F, Aditiawati P, Akhmaloka. 2007. 16S ribosomal RNA-based analysis of thermophilic bacteria in Gedongsongo hot spring. Microbiol Indones 1:37-42.

Ashby MN, Rine J, Mongodin EF, Nelson KE, Dimster-Denk D. 2007. Serial analysis of rRNA genes and the unexpected dominance of rare members of microbial communities. Appl Environ Microbiol 73:45324542.

Bassam BJ, Anolles CG, Greshoff PM. 1991. Fast and sensitive staining of DNA in polyacrylamide gels. Anal Biochem 196:80-83.

Bintrim SB, Donohue TJ, Handesman J, Robert GP, Goodman RM. 1997. Molecular phylogeny of Archaea from soil. Proc Natl Acad Sci 94:277282.

Chaudhuri SR, Pattanayak AK, Thakur AR. 2006. Microbial DNA extraction from samples of varied origin. Current Science 91:16971700.

Felsenstein J. 1989. PHYLIP- phylogeny inference package. Cladistic 5:164-166.

Ferris MJ, Muyzer G, Ward DM. 1996. Denaturing gradient gel electrophoresis profiles of 16S rRNA-defined populations inhabiting a hot spring microbial mat community. Appl Environ Microbiol 62:340-346.

Frostegard A, Courtois S, Ramisse V, Clerc S, Bernillon D, LeGall F, Jeanin P, Nesme X, Simonet P. 1999. Quantification of bias related to the extraction of DNA directly from soils. Appl Environ Microbiol 65:5409-5420.

Heuer H, Hartung K, Wieland G, Kramer I, Smalla K. 1999. Polynucleotide probes that target a hypervariable region of $16 \mathrm{~S}$ rRNA gene to identify bacterial isolates corresponding to bands of community fingerprints. Appl Environ Microbiol 65:1045-1049.

Kresk M, Wellington EMH. 1999. Comparison of different methods for the isolation and purification of total community DNA from soil. $J$ Microbiol Methods 39:1-16.

Liesack W, Janssen PH, Rainey FA, Ward-Rainey NL, Stackebrandt E. 1997. Microbial diversity in soil: the need for a combined approach using molecular and cultivation techniques. In: van Elsas JD, Trevors JT and Wellington EMH (eds) Modern Soil Microbiology. New York: Marcel Dekker. pp 375-439.

Lohr AJ, Laverman AM, Braster M, van Straalen NM, Roling WFM. 2006. Microbial communities in the world's largest acidic volcanic lake, Kawah Ijen in Indonesia, and in the Banyupahit river originating from it. Microbial Ecology 52:609-618.
Marsh TL, Saxman P, Cole J, Tiedje J. 2000. Terminal restriction fragment length polymorphism analysis program, a web-based research tool for microbial community analysis. Appl Environ Microbiol 66:3616-3620.

Muyzer G, De Wall EC, Uitterlinden AG. 1993. profiling of complex microbial population by denaturing gradient gel electrophoresis analysis of polymerase chain reaction-amplified genes coding for $16 \mathrm{~s}$ rRna. Appl Environ Microbiol 59:695-700.

Muyzer G, Smalla K. 1998. Application of denaturing gradient gel electrophoresis (DGGE) and temperature gradient gel electrophoresis (TGGE) in microbial ecology. Antonie van Leeuwenhoek 73:127-141.

Nadkarni MA, Martin FE, Jacques NA, Hunter N. 2002. Determination of bacterial load by real-time PCR using a broad-range (universal) probe and primers set. Microbiology 148:257-266.

Nakagawa T, Fukui M. 2003. Molecular characterization of community structures and sulfur metabolism within microbial streamers in japanese hot springs. Appl Environ Microbiol 69:7044-7057.

Sait M, Davis KER, Janssen PH. 2006. Effect of $\mathrm{pH}$ on isolation and distribution of members of subdivision 1 of the phylum acidobacteria occurring in soil. Appl Environ Microbiol 72:1852-1857.

Saitou N, Nei M. 1987. The neighbor-joining method: a new method for reconstructing phylogenetic trees. Mol Biol Evol 4:406-425.

Sekiguchi H, Watanabe W, Nakahara T, Xu B, Uchiyama H. 2002. Succession of bacterial community structure along the changjiang river determined by denaturating gradient gel electrophoresis and clone library analysis. Appl Environ Microbiol 68:5142-5150.

Skirnisdottir S, Hreggvidsson GO, Holst O, Kristjansson JK. 2001. A new ecological adaptation to high sulfide by a HidrogenobacterI sp. growing on sulfur compound but not on hydrogen. Microbiol Res 156:41-47.

Spear JR, Barton HA, Robertson CE, Francis CA, Pace NR. 2007. Microbial community biofabrics in a geothermal mine adit. Appl Environ Microbiol 73:6172-6180.

Ward DM, Ferris MJ, Nold SJ, Bateson MM. 1998. A natural view of microbial diversity within hot spring cyanobacterial mat communities. Microbiol Mol Biol Rev 62:1353-1370.

Zengler K, Toledo G, Rappé M, Elkins J, Mathur EJ, Sort JM, Keller M. 2002. Cultivating the uncultured. Proc Natl Acad Sci 99:15681-15686.

Zhou J, Bruns MA, Tiedje JM. 1996. DNA recovery from soils of diverse composition. Appl Environ Microbiol 62:316-322. 